\title{
20 Katlı Betonarme Yapının Farklı Perde Duvar Yerleşimlerine Göre Deprem Analizi
}

\author{
Özge Onat ${ }^{1}$, Pınar Usta ${ }^{2 *}$ \\ 1* Isparta Uygulamalı Bilimler Üniversitesi, Lisansüstü Eğitim Enstitüsü, İnşaat Mühendisliği Bölümü, Isparta, Türkiye, (ORCID: 0000-0002-4336-0212), \\ onatozge09@gmail.com \\ 2* Isparta Uygulamalı Bilimler Üniversitesi, Teknoloji Fakültesi, İnşaat Mühendisliği Bölümü, Isparta, Türkiye (ORCID: 0000-0001-9809-3855), \\ pinarusta@isparta.edu.tr
}

(İlk Geliş Tarihi 9 Nisan 2021 ve Kabul Tarihi 27 Haziran 2021)

(DOI: $10.31590 /$ ejosat.912625)

ATIF/REFERENCE: Onat, Ö., \& Usta, P. (2021). 20 Katlı Betonarme Yapının Farklı Perde Duvar Yerleşimlerine Göre Deprem Analizi. Avrupa Bilim ve Teknoloji Dergisi, (25), 363-369.

\section{Öz}

Özellikle son yıllarda yüksek katlı konut ve ticari binaların inşaatında belirgin bir şekilde artış meydana gelmiştir. Bu belirgin artış nedeniyle, deprem yükü gibi yanal yüklerin etkisi, depreme karşı yeterli güç ve dayanım sağlama problemleri fazlaca dikkat çekmiştir. Şiddetli depremler yüksek binalarda ağır hasarlara veya çökmelere neden olabilirler. Yapılan akademik çalışmalar depremden kaynaklanan yapısal hasarın büyük yer değiştirmenin nedeni olduğunu göstermiştir. Perde duvarlar bina veya yapıya yanal direnç sağlayan bir tür yapısal sistemdir. Perde duvar sistemleri ile yüksek yapılara etki eden yanal yüklerin etkisine karşı konularak binaya gelen yanal yükler azaltılmaktadır. Böylece, binalarda perde duvarların kullanılması büyük yer değiştirmeyi ve bu yer değiştirmeden kaynaklanan hasarları önleyebilmektedir.

$\mathrm{Bu}$ çalışmada; yüksek betonarme yapılarda kullanılan perdelerin ve perdelerin yapılarda yerleşim şekillerinin yapı deprem performansı üzerindeki etkilerini araştırmak amaçlanmıştır. Bu nedenle betonarme çerçeve taşıyıcı sisteme sahip 20 kattan oluşan bir betonarme yapı ele alınmış ve farklı perde yerleşim şekline sahip olacak şekilde 4 farklı model oluşturulmuştur. Yapının modellemesi ve deprem analizlerinde SAP2000 V22 sonlu elemanlar programı kullanılmıştır.

\section{Earthquake Analysis Of The 20 Storey Reinforced Concrete Building According To Different Shear Wall Placements}

\begin{abstract}
Especially in recent years, there has been a marked increase in the construction of tall residential and commercial buildings. Due to this significant increase, the effects of lateral loads such as earthquake loads and the problems of providing sufficient strength and resistance against earthquakes have attracted much attention. Severe earthquakes could cause severe damage or collapse in tall buildings. Academic studies have shown that structural damage caused by the earthquake is the cause of the large displacement. Shear walls are a type of structural system that provides lateral resistance to a building or structure. With Shearwall systems, the lateral loads on the building are reduced by countering the effects of lateral loads on high buildings. Thus, the use of shearwalls in buildings could prevent large displacement and damage caused by this displacement. The aim of this study is to investigate the effects and behaviour of the shear walls, which have different placement, performance of the building under the earthquake loads. To the aim, a reinforced concrete structure with 20 stories have been modelled by SAP2000 V22 finite element program to conducted earthquake analysis of the structure.
\end{abstract}

*Sorumlu Yazar: onatozge09@gmail.com 
Keywords: Shear wall, SAP2000, Building, Earthquake.

\section{Giriş}

Köylerden şehirlere olan göçler arttıkça şehirlerde nüfus artmıştır. Şehirlerde olan bu kalabalık nüfusun barınma ihtiyacını ekonomik olarak karşılamak için binalar yüksek katlı olarak tasarlanmaya başlanmıştır (Şahin, Alyamaç, Erdoğan, 2013: 74). Yüksek binalar yapıldıkça yatay yüklerin etkisi (deprem veya rüzgâr gibi yükler) binaların tasarımında önem kazanmıştır (Othman, 2017: 1). Ülkemizin alanlarının \%92'si deprem aktivitesinin yoğun olduğu kuşakta yer almaktadır (Öztürk, 2005: 1). Bu nedenle depremin yıkıcı olması, can ve mal kaybına yol açmaktadır. Deprem kuşağında yer alan şehirler için depremden gelen yatay yükleri karşılaması, binanın taşıyıcı sisteminin tasarımının düzgün yapılması önemlidir. Bir binanın deprem güvenliğine en çok katkı sağlayan taşıyıcı elemanlar perde duvarlardır (Yaman, Tekeli, Demir; 2019: 195:)

Perde duvarlar, yatay kuvvetleri karşılayan dikey elemanlardır (Kadakia, Patel Arya, 2017: 389). Perde duvarlar binalarda yanal yükler etkisi ile oluşan eğilme momentleri karşılamak için kullanılır (Dyavappanavar, Manjunatha, Kavya, 2015: 214). Perde duvarla tasarlanmış yapının deprem dayanımı ve deprem performansının arttı̆̆1, yanal ötelemenin azaldığ belirlenmiştir (Öztürk, Çağlar, Dok, Yüksel, 2017: 1892).

Deprem sırasında meydana gelen hasarlar incelendiğinde, perde duvar ile tasarlanmış binaların çerçeve ile tasarlanmış binalardan daha az hasar aldığı görülmüștür (Şahin ve diğerleri, 2013: 76). Perde duvarların düzgün konumlanmadığı yapılarda deprem sırasında fazla yanal ötelemeye maruz kaldığ 1 için binaların yıkıldığı görülmüştür (Koç, 2016: 50). Bu nedenle perde duvarlar yüksek yapılarda yatay yüklerin karşılanması için kullanılırlar (Aktan ve Kıraç, 2010: 16).

Perde duvarlar ile ilgili literatürde yapılmış birçok çalışma bulunmaktadır; Damam, 2015; çalışmasında 11 katlı bir binayı 4 farklı deprem bölgesinde, perde duvarların konumlarını değiştirerek SAP2000 sonlu elemanlar programında modellemiştir. Modellenen binaların y yönündeki kat yatay yer değiştirmeleri ve kat öteleme değerlerini grafiklerle göstermiş ve çalışmasının sonucunda köşelerinde perde duvar bulunan modelin kat ötelemesinin en düşük olduğu sonucuna varmıştır (Damam, 2015: 1261-1266).

Dyavappanavar ve ark., 2015; çalışmalarında simetrik bir plana sahip 20 katlı bir binayı çerçeve sistem ve 4 farklı perde duvar yerleşimi ile SAP2000 sonlu elemanlar programında modellemesini yapışlardır. Modellenen binaların kendi yükleri altında, eşdeğer statik metot ve tepki spektrumu analizlerini yapmışlardır. Analizleri yapılan binaların x ve y yönlerinde kat öteleme değerlerini grafiklerle göstermişlerdir. Perde duvarları köşede olan tasarım daha az öteleme yaptığ sonucuna varmışlardır (Kadakia ve diğerleri, 2017: 388-397).

Gupta ve Pandey, 2019; çalışmalarında simetrik plana sahip 13 katlı bir binayı 2 farklı x çelik çaprazlı perde duvar yerleşimi ve 2 farklı betonarme perde duvar yerleşimi ile Staad pro Software programında modellemişlerdir. Analizi yapılan modeller eğilme momenti, kesme kuvveti, kat ötelemesi, taban kesme kuvvetleri ile karşılaştırmışlardır. Perde duvar ve çelik perde ile modellenmiş binaların kat ötelemeleri önemli ölçüde düştüğü sonucuna varmışlardır. En az öteleme betonarme perde duvarın dış köşe akslarda modellenen binada olduğunu sonucuna varmışlardır (Gupta ve Pandey, 2016: 1963-1966).
Othman, 2017; çalışmasında 5, 10, 20 ve 30 katlı binaları çerçeveli sistem ve 3 farklı perde duvar yerleşimi ile toplam 16 farklı yapı modelini ETABS programında modellemiştir. Modellenen yapıları mod birleştirme yöntemi ile analizini yapmıştır. Perdelerin yerleşimi ve perdelerde bırakılacak boşluk oranının deprem davranışına etkisini incelemek için doğal titreşim periyodu, global ötelenme oranı, göreli ötelenme oranı ve perdelerin taban kesme kuvvetlerini karşılaştırmıştır. Perde duvarı dış akslarda ortada olan modelin en düşük değerleri aldığı sonucuna varmıştır (Şahin ve diğerleri, 2013: 74-86).

Prajapati ve ark., 2016; çalışmalarında simetrik plana sahip bir binayı 35 katlı çerçeve sistem ve perde duvarlı, 47 katlı perde duvarlı ve hem perde duvarlı hem de x çelik çaprazlı perde duvarlı olarak ETABS Software programı ile modellemişlerdir. Analizi yapılan modeller kat ötelenmeleri, kat kuvvetleri, kat kesme kuvvetleri, devrilme momentleri, burulma düzensizliği ve mod şekilleri ile karşılaştırmışlardır. 47 katlı hem perde duvarlı hem de $\mathrm{x}$ çelik çaprazlı perde duvar olan modelin yer değiştirmesinin \%40 azaldığını tespit etmişlerdir (Prajapati, Patel, Patel, 2016: 1963-1966).

Sakcalı, 2019; çalışmasında simetrik kalıp planına sahip 3 katlı bina için farklı kolon boyutları yerleştirmiştir. 7 farklı deprem kaydını ölçeklendirerek Seismostruct yazılımı ile binanın yapısal performansını incelemiştir. Sonuçlarını inceleyerek perde duvar yerleşimini yapmıştır. Tasarladığg binalara dinamik analizler yapmıştır. Analiz sonucunda perde duvar oranının artması deformasyonları azalttığı gözlemlemiştir (Sakcal1, 2019: 1-9).

Aktan ve Kıraç, 2010; Uçar ve Merter, 2009; Yaman ve ark., 2019; çalışmalarında perde duvar yerleşiminin yapının deprem performansına etkisini araştırmışlardır. Dış akslara konulan perde duvarların deprem performansında yatay yer değiştirmenin daha az olduğunu ifade etmişlerdir (Akman ve Kıraç, 2010:1532) (Uçar ve Merter, 2009: 11-18) (Yaman ve diğerleri,2019: 194-204).

$\mathrm{Bu}$ çalışmada, perde duvarların yapıda yerleşim şekillerinin yap1 deprem performansını nasıl etkilediği incelenmiştir. $\mathrm{Bu}$ amaçla 20 katlı konut türü betonarme sadece çerçeveli ve farklı oranlarda perde duvar yerleştirilerek tasarlanan çerçeveli-perdeli binaların deprem performansları belirlenmiştir. Yapılan çalışmada değişik perde oranları ile bina performansı arasındaki ilişki doğrusal elastik olmayan yöntem kullanılarak incelenmiştir.

\section{Yapının Özellikleri ve Modellenmesi}

Çalışmada perde duvar oranının bina yapısal sistemine etkisini incelemek ve farklı oranlarda perde yapı elemanlarına sahip yapıların deprem performansını karşılaştırmak için çerçeveli model (ÇM), perde duvarları dış köşelerde olan perdeli model (PM1), perde duvarları dış ortada olan perdeli model (PM2), perde duvarları iç köşelerde olan perdeli model (PM3), perde duvarları merkez (çekirdekte) olan perdeli model (PM4) olmak üzere tasarlanarak, yapı modeli çerçeve sistemli ve 4 farklı perde duvar yerleşimi ile SAP2000 sonlu elemanları programı kullanılarak modellenmiştir. Modellenen binaların kat planları ve bu planlar üzerindeki perdelerin yerleşim konumları Şekil 1, Şekil 2, Şekil 3, Şekil 4, Şekil 5'te verilmiştir. 

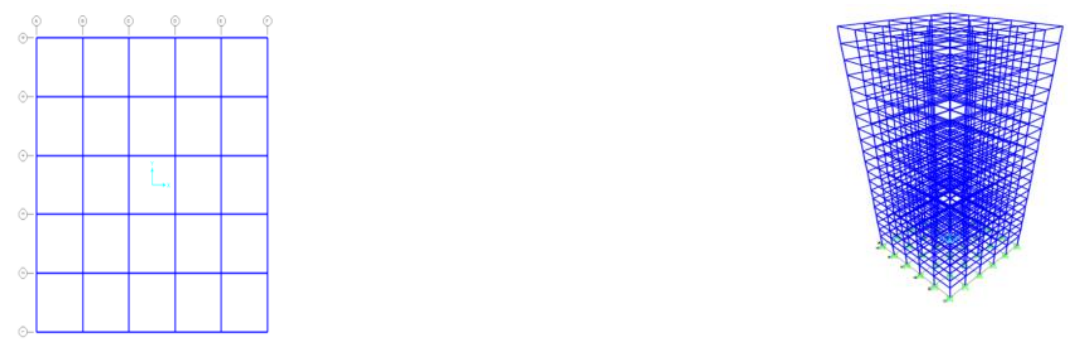

Şekil 1. Çerçeve sistemli modelin xy planı ve 3d görüntüsü (ÇM)
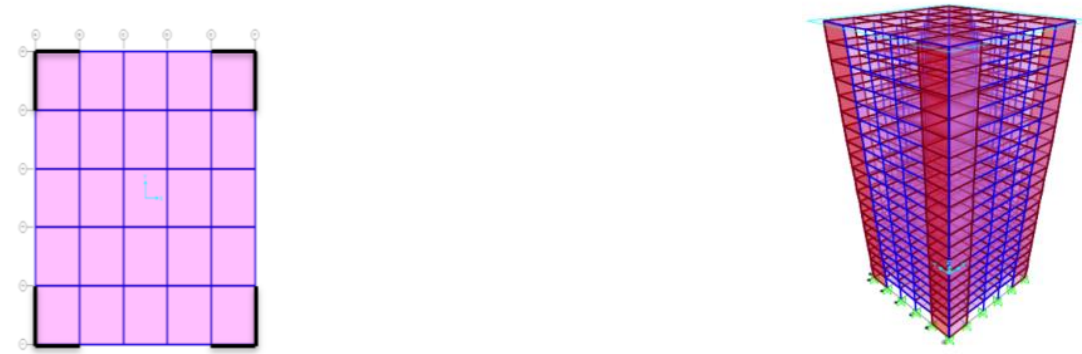

Şekil 2. Perde duvarları dış köşelerde olan modelin xy planı ve 3d görüntüsü (PM1)
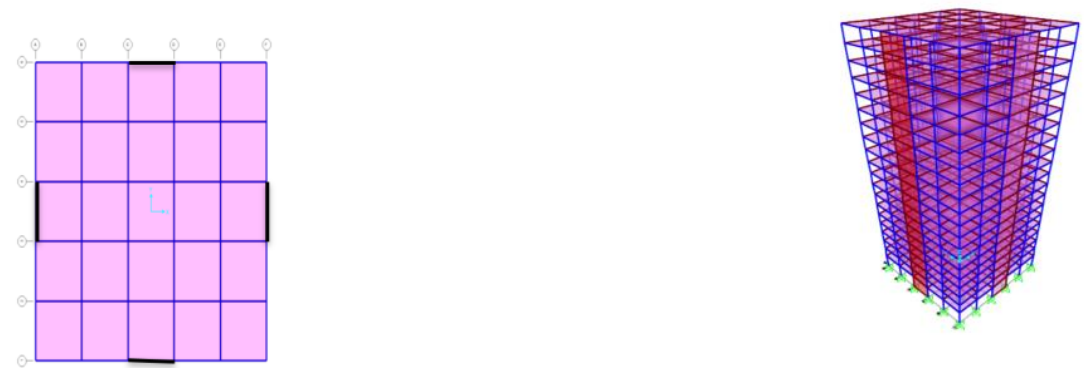

Şekil 3. Perde duvarları dış ortada olan modelin xy planı ve 3 d görüntüsü (PM2)
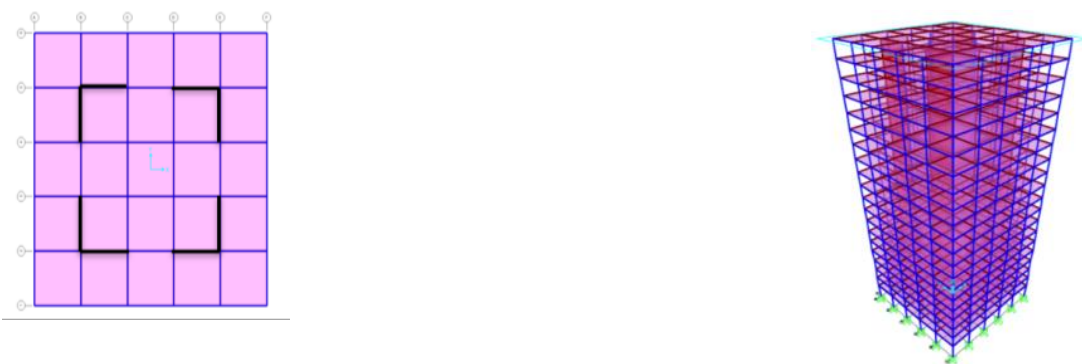

Şekil 4. Perde duvarları iç köşelerde olan modelin xy planı ve $3 d$ görüntüsü (PM3)
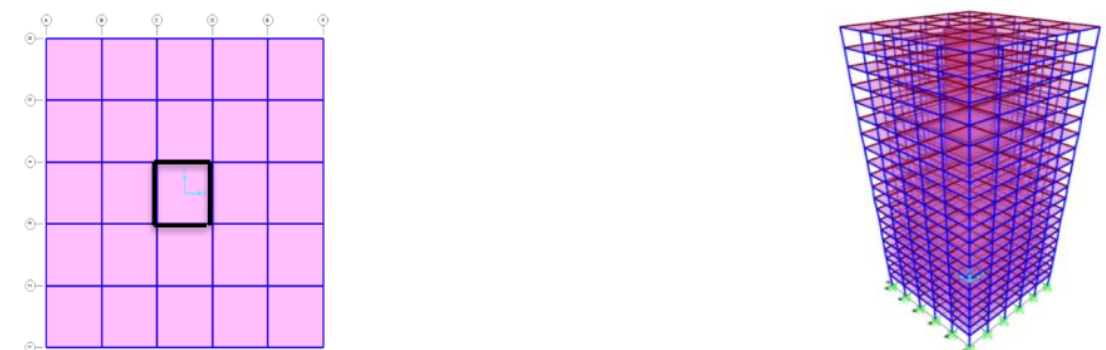

Şekil 5. Perde duvarları merkez (çekirdekte) olan modelin xy planı ve 3d görüntüsü (PM4) 
Modellenen yapılar aynı kat alanlarına sahip olmakla birlikte simetriktir ve her kat $3,2 \mathrm{~m}$ yüksekliğe sahiptir. Perdeler bina akslarına konumlandırılırken simetriye dikkat edilerek yerleştirilmiştir. Seçilen örnek binalarda beton sınıfı ve çelik malzeme olarak C30-B420C kullanılmıştır. Model binalarda kat yükseklikleri 3,2 m alınmıştır. Kolon, kiriş boyutları her katta ayn1 olup sirasi ile 1,00x1,00 m- 0,50x0,80 m olarak belirlenmiştir. Döşeme kalınlıkları 0,15 m, perde duvar kalınlığ ise $0,5 \mathrm{~m}$ olarak tanımlanmıştır. Bina Önem katsayısı $\mathrm{I}=1.0$ olan bu binaların ZC yerel zemin sınıfı üzerinde inşa edildiği kabul edilmiştir. Çerçeve sisteme sahip model için taşıyıcı sistem davranış katsayısı $\mathrm{R}=8$, deprem yüklerinin çerçeveler ve perdeler tarafından birlikte taşındığı yüksek süneklik düzeyine sahip perdeli modeller için ise taşıyıcı sistem davranış katsayısı $\mathrm{R}=7$ olarak alınmıştır. Döşemeler üzerinde düzgün yayılı yük $1.5 \mathrm{kN} / \mathrm{m} 2$ ölü yük (sıva+kaplama) ve $2 \mathrm{kN} / \mathrm{m} 2$ hareketli yük dikkate alınmıştır. Kirişler üzerinde $3 \mathrm{kN} / \mathrm{m} 2$ duvar yükü (tuğla+sıva) öngörülmüştür. Hareketli yük katılım sayısı $n=0.3$ alınmıştır. Elemanların öz ağırlıkları Sap2000 sonlu elamanlar programına tanımlanarak alınmıştır. Sap2000 programında modeller oluşturulurken kiriş ve kolonlar çubuk eleman, kat döşemeleri ve perdeler ise shell elemanlar ile modellenmiştir.

\section{Araştırma Sonuçları ve Tartışma}

Çalışmada kullanılan binaların yönetmelikte (TBDY, 2018) verilen dört farklı deprem düzeyine göre deprem analizleri Response Spektrum analiz yöntemi kullanılarak binaların üç boyutlu hesap modelleri üzerinden SAP2000 sonlu elemanlar programı kullanılarak gerçekleştirilmiştir. Dört farklı deprem düzeyine ait yatay elastik tasarım spektrumlarına ait grafikler Şekil 6'da verilmiştir.

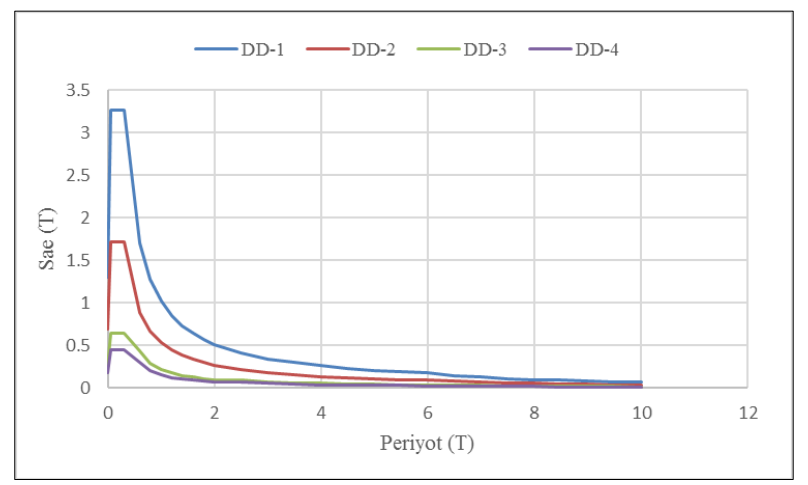

Şekil 6. Farklı deprem düzeylerine göre yatay elastik tasarım spektrumlart

Farklı modeller üzerinde dört farklı deprem düzeyine ait spektral ivmeler kullanılarak yapılan modal analiz neticesinde modellere ait periyot değerleri ve response spektrum deprem analizleri neticesinde ise yap1 modellerine ait göreli kat ötelemeleri, katlara göre kesme ve moment kuvveti değerleri bulunmuştur. Yapılan analizler sonucunda 5 farklı modele ait periyotlar Şekil 7'de verilmiştir.

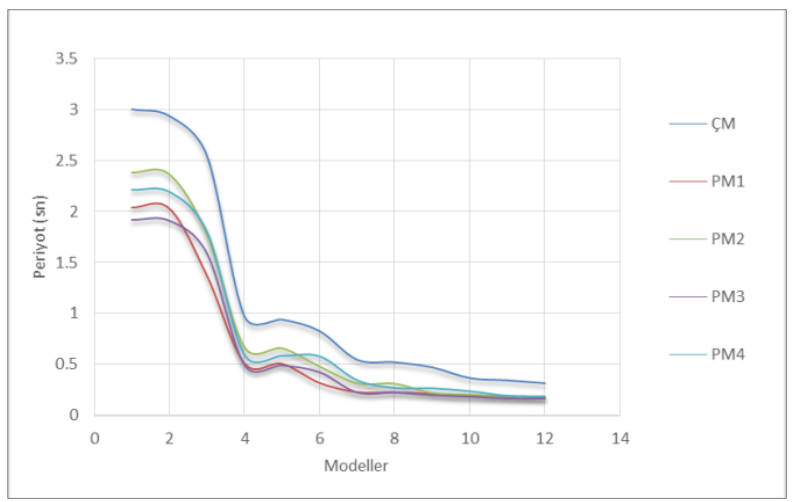

Şekil 7. Modeller ve periyot değgerleri

Şekil 7 de görüldüğü gibi periyotlar sırası ile çerçeveli modelde 2,99 sn, perdeli model 2'de 2,38 sn, perdeli model 4'de 2,21 sn, perdeli model 1'de 2,03 sn, perdeli model 3'de 1,91 sn olarak bulunmuştur. Grafik değerleri incelendiğinde çerçeveli modele ait periyot değerinin en yüksek çıktığı görülmektedir.

Modellerin her iki deprem doğrultusunda etkin göreli kat ötelemeleri hesabı TBDY (2018) esas alınarak yapılmış ve elde edilen verilerin yönetmelikte verilen sınır değerleri aşıp aşmadığı kontrol edilmiştir. TBDY (2018) yönetmeliğinde ise $\lambda$ katsayısı hesaplanarak bu sınır değer belirlenmektedir ve aşağıdaki formül ile hesaplama yapılmaktadır.

$$
\lambda \frac{\delta_{i, \max }^{(x)}}{h_{i}} \leq 0.008 \kappa
$$

Modellerin etkin göreli kat öteleme oranları Şekil 8, Şekil 9, Şekil 10, Şekil 11'de görülmektedir.

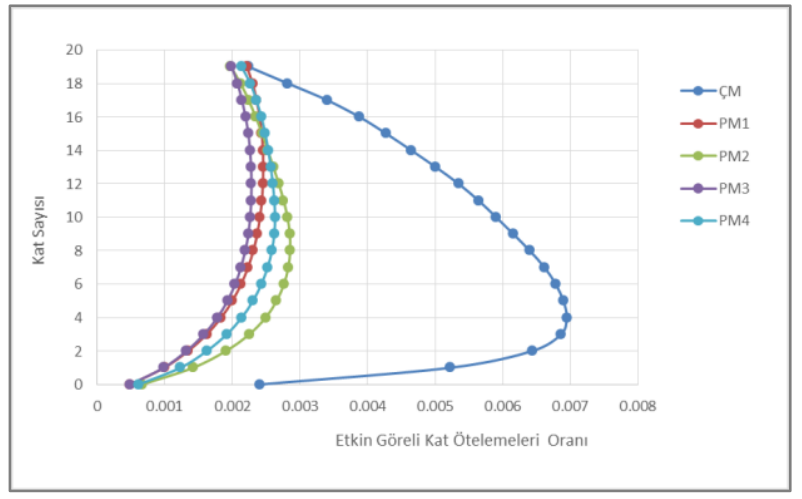

Şekil 8. DD-1'e göre modellerin etkin göreli kat ötelemesi oranı

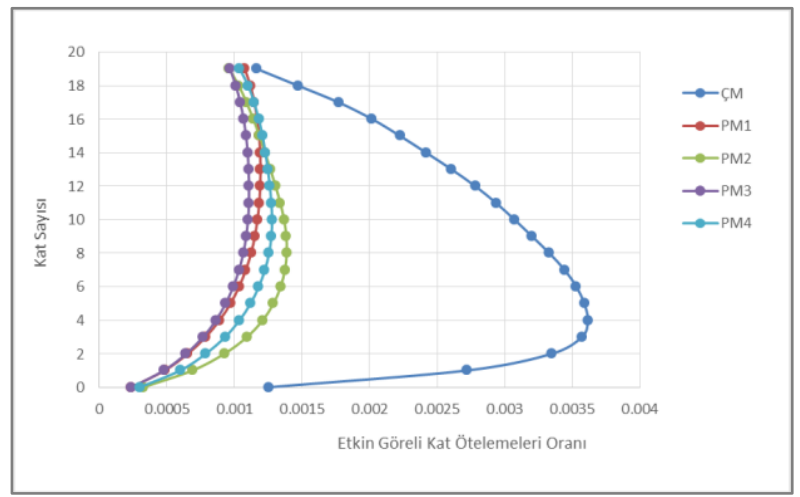

Şekil 9. DD-2'e göre modellerin etkin göreli kat ötelemesi oranı 


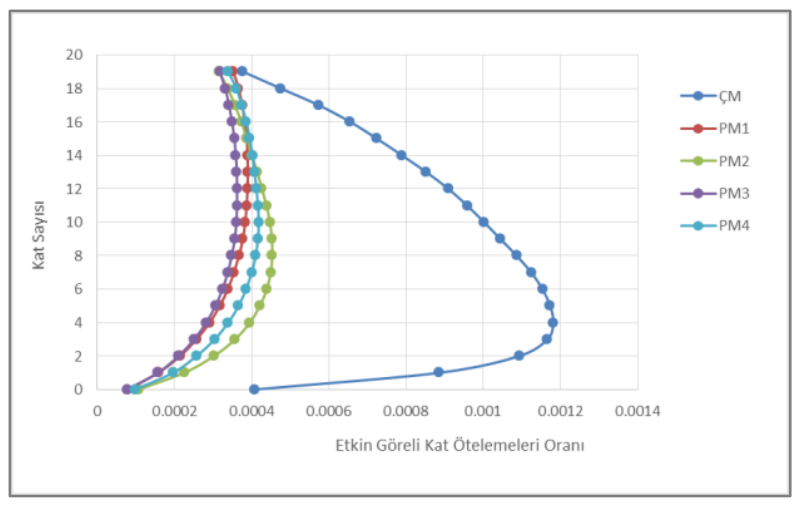

Şekil 10. DD-3'e göre modellerin etkin göreli kat ötelemesi oranı

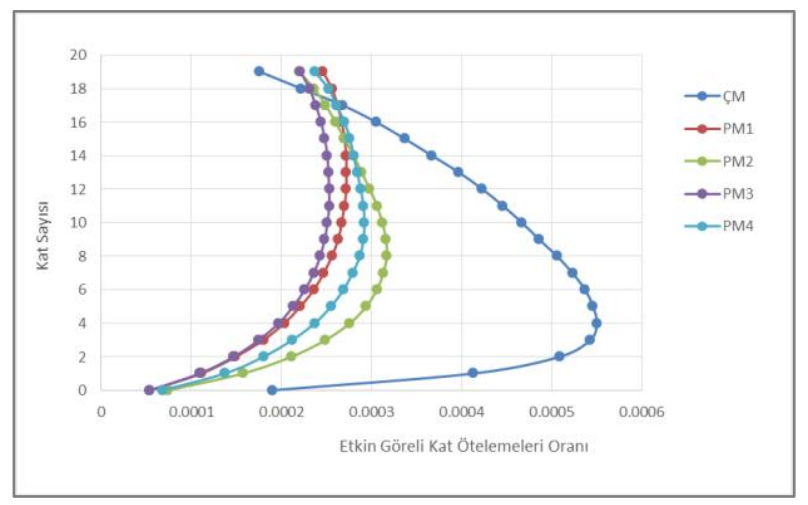

Şekil 11. DD-4'e göre modellerin etkin göreli kat ötelemesi oranı

DD-1 için yapılan analizler sonucunda modellere ait $\mathrm{X}$ doğrultusunda maksimum etkin göreli kat ötelemesi oranı çerçeveli modelin 4. katında meydana gelmiştir ve değeri 0,00695 olarak hesaplanmıştır. DD-2 için yapılan analizler sonucunda modellere ait $\mathrm{X}$ doğrultusunda maksimum etkin göreli kat ötelemesi oranı çerçeveli modelin 4. katında meydana gelmiştir ve değeri 0,00362 olarak hesaplanmıştır. DD-3 için yapılan analizler sonucunda modellere ait $\mathrm{X}$ doğrultusunda maksimum etkin göreli kat ötelemesi oranı çerçeveli modelin 4. katında meydana gelmiştir ve değeri 0,00118 olarak hesaplanmıştır. DD-4 için yapılan analizler sonucunda modellere ait $\mathrm{X}$ doğrultusunda maksimum etkin göreli kat ötelemesi oranı çerçeveli modelin 4. katında meydana gelmiştir ve değeri 0,00055 olarak hesaplanmıștır.

DD-1 için yapılan analizler sonucunda modellere ait $\mathrm{X}$ doğrultusunda minimum etkin göreli kat ötelemesi oranı perdeli model 3'ün 1. katında meydana gelmiştir ve değeri 0,00049 olarak hesaplanmıştır. DD-2 için yapılan analizler sonucunda modellere ait $\mathrm{X}$ doğrultusunda minimum etkin göreli kat ötelemesi oranı perdeli model 3'ün 1. katında meydana gelmiştir ve değeri 0,00024 olarak hesaplanmıştır. DD-3 için yapılan analizler sonucunda modellere ait $\mathrm{X}$ doğrultusunda minimum etkin göreli kat ötelemesi oranı perdeli model 3'ün 1. katında meydana gelmiştir ve değeri 0,00008 olarak hesaplanmıştır. DD4 için yapılan analizler sonucunda modellere ait $\mathrm{X}$ doğrultusunda minimum etkin göreli kat ötelemesi oranı perdeli model 3'ün 1. katında meydana gelmiştir ve değeri 0,00005 olarak hesaplanmıştır.

Deprem düzeylerine göre tüm katlarda $X$ yönü için hesaplanan kesme kuvveti değerleri Şekil 12, Şekil 13, Şekil 14, Şekil 15'da karşılaştırmalı olarak sunulmuştur.

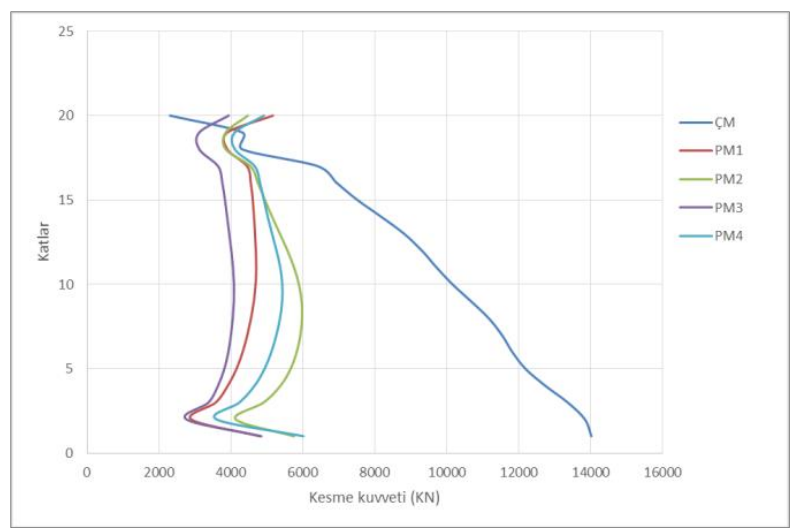

Şekil 12. DD-1'e göre Modellerin katlara göre X yönü kesme kuvvetleri $(k N)$

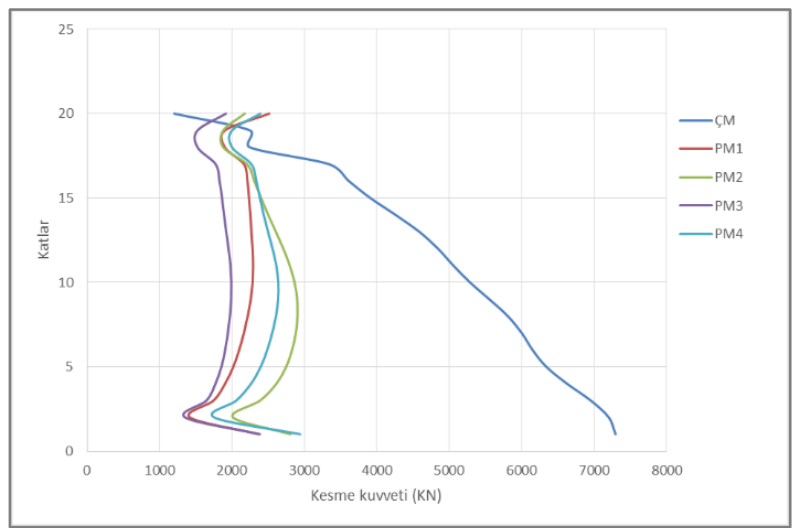

Şekil 13. DD-2'e göre Modellerin katlara göre X yönü kesme kuvvetleri $(k N)$

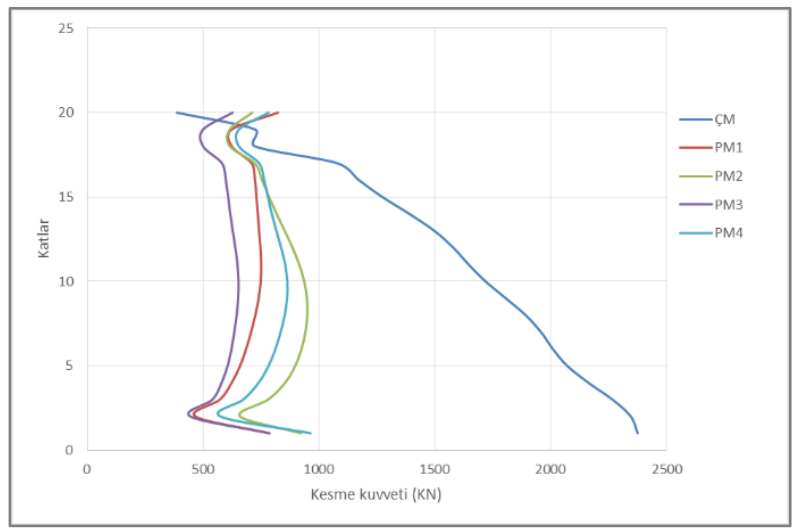

Sekil 14. DD-3'e göre Modellerin katlara göre X yönü kesme kuvvetleri $(k N)$

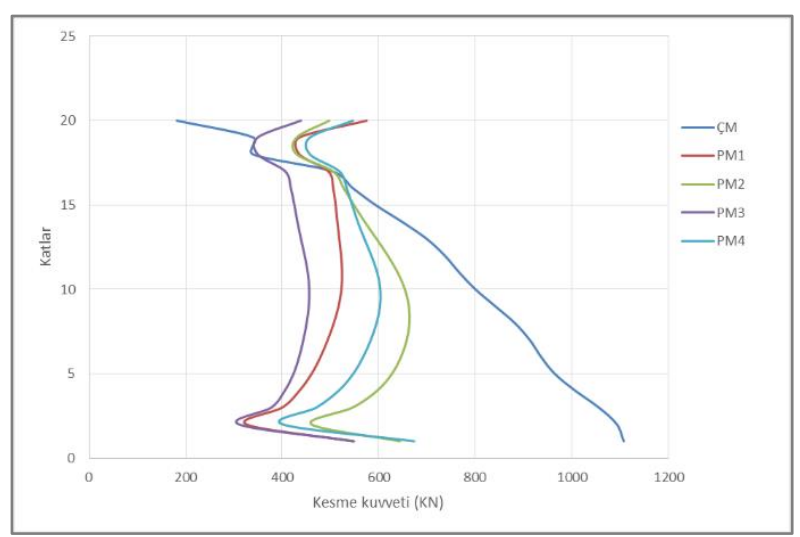


Şekil 15. DD-4'e göre Modellerin katlara göre X yönü kesme kuvvetleri $(k N)$

Modellerin kat kesme kuvvetleri incelendiğinde DD-1 deprem düzeylerine göre $\mathrm{X}$ yönü en büyük kat kesme kuvveti çerçeveli modelin 1. katında meydana gelmiştir ve değeri $14012,6 \mathrm{kN}$ olarak hesaplanmıştır. DD-2 deprem düzeylerine göre en X yönü en büyük kat kesme kuvveti çerçeveli modelin 1 . katında meydana gelmiştir ve değeri 7294,1 kN olarak hesaplanmıştır. DD-3 deprem düzeylerine göre en $\mathrm{X}$ yönü en büyük kat kesme kuvveti çerçeveli modelin 1. katında meydana gelmiştir ve değeri $2374,8 \mathrm{kN}$ olarak hesaplanmıştır. DD-4 deprem düzeylerine göre en $\mathrm{X}$ yönü en büyük kat kesme kuvveti çerçeveli modelin 1. katında meydana gelmiştir ve değeri 1106,9 $\mathrm{kN}$ olarak hesaplanmıştır.

Modellerin kat kesme kuvvetleri incelendiğinde DD-1 deprem düzeylerine göre $\mathrm{X}$ yönü en küçük kat kesme kuvveti çerçeveli modelin 20. katında meydana gelmiştir ve değeri 2303,7 kN olarak hesaplanmıştır. DD-2 deprem düzeylerine göre en $X$ yönü en küçük kat kesme kuvveti çerçeveli modelin 20 . katında meydana gelmiştir ve değeri $1201,6 \mathrm{kN}$ olarak hesaplanmıştır. DD-3 deprem düzeylerine göre en $\mathrm{X}$ yönü en küçük kat kesme kuvveti çerçeveli modelin 20. katında meydana gelmiştir ve değeri 386,9 olarak hesaplanmıştır. DD-4 deprem düzeylerine göre en $\mathrm{X}$ yönü en küçük kat kesme kuvveti çerçeveli modelin 20. katında meydana gelmiştir ve değeri 181,8 olarak hesaplanmıştır.

Deprem düzeylerine göre tüm katlarda $X$ yönü için hesaplanan moment değerleri Şekil 16, Şekil 17, Şekil 18, Şekil 19'da karşılaştırmalı olarak sunulmuştur.

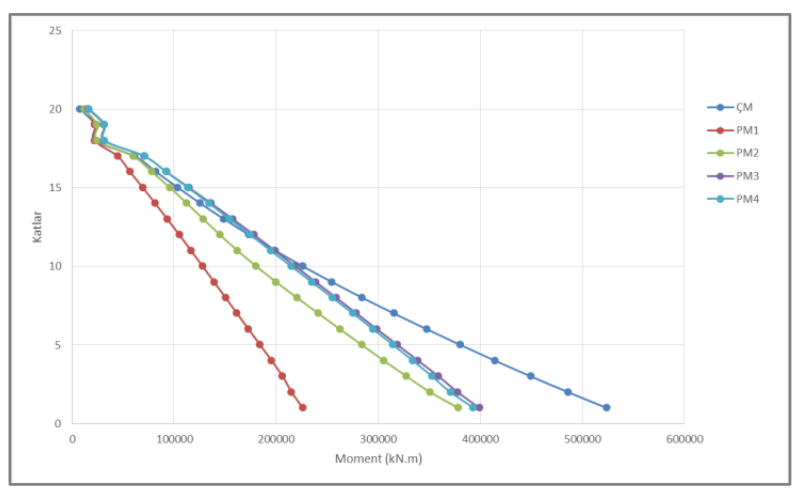

Şekil 16. DD-1'e göre Modellerin katlara göre X yönü moment kuvvetleri değerleri (kN.m)

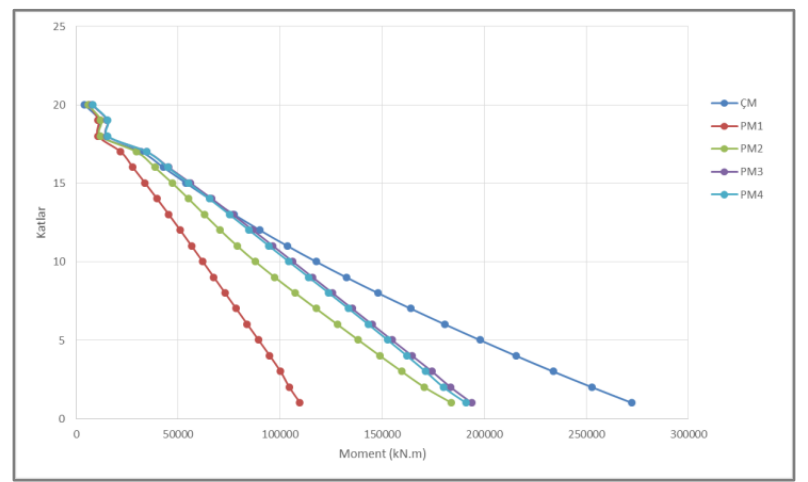

Şekil 17. DD-2'e göre Modellerin katlara göre X yönü moment kuvvetleri değerleri (kN.m)

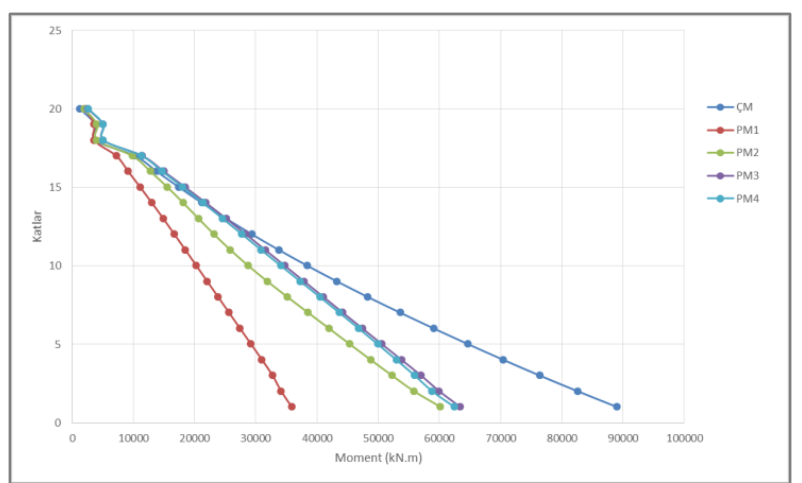

Şekil 18. DD-3'e göre Modellerin katlara göre X yönü moment kuvvetleri değerleri ( $k$ N.m)

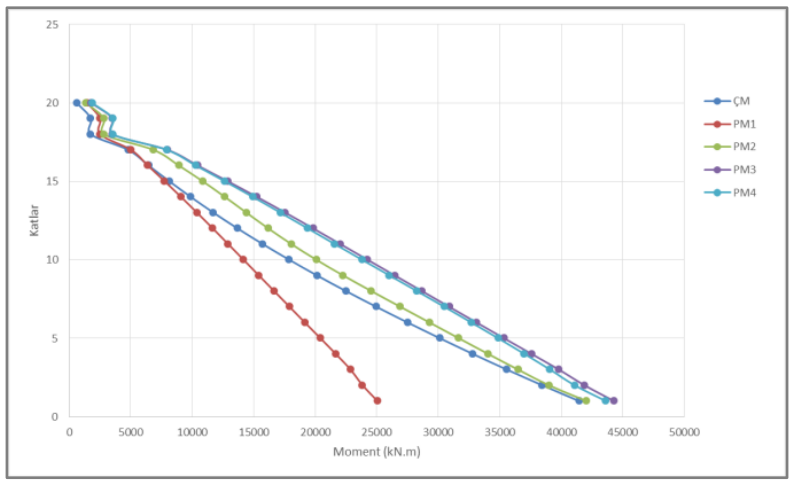

Şekil 19. DD-4'e göre Modellerin katlara göre X yönü moment kuvvetleri değerleri (kN.m)

Moment değerlerine bakıldığında ise tahmin edileceği üzere kesme kuvvetinin en büyük değere ulaştığı katta moment değeri de maksimumdur. Modellerin moment değerleri incelendiğinde DD-1 deprem düzeylerine göre en $\mathrm{X}$ yönü en büyük moment değeri çerçeveli modelin 1. katında meydana gelmiştir ve değeri 523855,1 kN.m olarak hesaplanmıştır. DD-2 deprem düzeylerine göre en $X$ yönü en büyük moment değeri çerçeveli modelin 1 . katında meydana gelmiştir ve değeri 272578,1 kN.m olarak hesaplanmıştır. DD-3 deprem düzeylerine göre en $\mathrm{X}$ yönü en büyük moment değeri çerçeveli modelin 1. katında meydana gelmiştir ve değeri 89045,3 kN.m olarak hesaplanmıştır. DD-4 deprem düzeylerine göre en $\mathrm{X}$ yönü en büyük moment değeri perdeli model 3'ün 1. katında meydana gelmiştir ve değeri 44284,8 kN.m olarak hesaplanmıştır.

Modellerin moment değerleri incelendiğinde DD-1 deprem düzeylerine göre en $\mathrm{X}$ yönü en küçük moment değeri çerçeveli modelin 20. katında meydana gelmiştir ve değeri 7930,1 kN.m olarak hesaplanmıştır. DD-2 deprem düzeylerine göre en $\mathrm{X}$ yönü en küçük moment değeri çerçeveli modelin 20. katında meydana gelmiştir ve değeri 4136,6 kN.m olarak hesaplanmıştır. DD-3 deprem düzeylerine göre en $\mathrm{X}$ yönü en küçük moment değeri çerçeveli modelin 20. katında meydana gelmiştir ve değeri 1332,1 kN.m olarak hesaplanmıştır. DD-4 deprem düzeylerine göre en $\mathrm{X}$ yönü en küçük moment değeri çerçeveli modelin 20. katında meydana gelmiştir ve değeri 626,4 kN.m olarak hesaplanmıştır.

Tüm katlar için moment değerleri incelendiğinde çerçeveli modelde maksimum değerlere ulaşıldığg görülmektedir.

Moment kuvvetlerinin de kesme kuvveti değerlerine bağlı olarak üst katlara çıkıldıkça aradaki farkların giderek azaldığı görülmektedir. Yapının deprem yüklerinin çok büyük bir kısmını 
perdelerin taşıdığı modellerde oluşan kesme kuvveti ve moment farklarına nazaran çerçeveli modellerde oluşan farklar çok daha fazla hesaplanmıştır.

\section{Sonuç}

Bu çalışmada; yüksek katlı yapıların taşıyıcı sistemlerinde betonarme perde duvar elemanlarının deprem performansına etkileri incelenmiştir. 20 katlı bir betonarme yapı çerçeve sistem ve farklı konumlandırılmış perde elemanlı olarak Sap2000 sonlu elemanlar programında modellenmiş ve dört farklı deprem düzeyine göre yapıların deprem analizleri yapılmıştır.

Tüm perdeli-çerçeveli modellerde, planda perdelerin kesit alanlarının kat alanlarına oranı eşittir sistemdeki tüm perde, kolon ve kirişler için yönetmelik çerçevesinde etkin (çatlamış kesit-(EI)e) eğilme rijitlikleri kullanılmıştır.

Modellere ait periyot değerleri incelendiğinde en yüksek periyot değeri çerçeveli model yapısında, en düşük periyot değeri ise perdeli model 3 yapısında görülmüştür. En düşük değer ile en yüksek değer arasında yapı rijitliği açısından \%30 artış tespit edilmiştir.

Doğal titreşim periyodu, göreli ötelenme oranı açısından en etkin perdeli-çerçeveli modelin perdeli model 3 olduğu belirlenmiştir. Şöyle ki, diğer yapı modelleri ile karşılaştırıldığında en düşük doğal titreşim periyodu göreli kat ötelenmesi oranı bu model için elde edilmiştir.

Betonarme taşıyıcı sistemi çerçeveli ve perdeli-çerçeveli olan modellerin etkin göreli kat ötelemesi değerleri, katlara göre kesme kuvvetleri ve moment kuvvetleri elde edilmiştir. Değerler incelendiğinde maksimum değerlerin DD-1 deprem düzeyi ve çerçeveli modelde meydan geldiği görülmüştür.

Modellerdeki perde duvarların konumları dikkate alındığında perdeli model 3'de diğer modellere kıyasla daha yüksek rijitliğe sahiptir. Dolayısıyla modelin davranışında da beklenildiği gibi perdeli model 3'de x doğrultusu boyunca daha düşük yer değiştirmeler meydana gelmiştir. Ayrıca çerçeveli modele göre perdeli-çerçeveli modelde meydana gelen yer değiştirmeler de beklenildiği gibi daha düşük mertebelerdedir. Kat sayısı arttıkça perdelerin yapı davranışına katkısının azaldığı görülmüştür.

Farklı yerleşimli Perde duvarlara sahip modeller incelendiğinde; Perde duvarların L şeklinde yerleştirildiği perdeli model 3 ve perdeli model 1'in en az periyot ve göreli kat öteleme değerlerini aldığı ve betonarme yüksek katlı bina tasarımı yaparken perde duvarların bu şekillerde yerleşiminin diğer yerleşim biçimlerine göre daha güvenli olabileceği sonucuna varılmıştır.

\section{Kaynakça}

Aktan, S., \& Kıraç, N. (2010). Betonarme Binalarda Perdelerin Davranışa Etkileri. Eskişsehir Osmangazi Üniversitesi Mühendislik Mimarlık Fakültesi Dergisi, 15-32.

Damam, V. S. (2015). Comparative Study On Multistoried Rcc Structure With And Without Shear Wall By Using Sap2000 V17. International Research Journal Of Engineering And Technology, 2(7), 1261-1266.

Dyavappanavar, S. P., Manjunatha, K., \& Kavya, N. (2015). Seismic Analysis Of Rc Multi-Storied Structures With Shear Walls At Different Locations. International Research
Journal Of Engineering And Technology, 2.

Gupta, A. K., \& Pandey, V. Seismic Analysis Of High Rise Building With Shear Walls And Bracings.

Kadakia, R., Patel, V., \& Arya, A. (2017). Modelling And Analysis Of Irregular Geometrical Configured Rcc MultiStorey Building Using Shear Wall. Kalpa Publications İn Civil Engineering, 1, 388-397.

Koç, V. (2016). Deprem Sonrası Ağır Hasarlı Bina Hasarlarının Sınıflandırılması. Doğal Afetler Ve Çevre Dergisi, 2(1), 4665.

Othman, M. K. (2017). Çok Katlı Betonarme Yapılarda Perdelerin Planda Yerleşiminin Ve Perdelerdeki Boşlukların Deprem Davranışına Etkisi (Master's Thesis, Pamukkale Üniversitesi Fen Bilimleri Enstitüsü).

Öztürk, A., Çağlar, N., Dok, G., \& Yüksel, M. (2017). Betonarme Perdelerin Betonarme Yüksek Binaların Deprem Performansina Etkileri.

Öztürk, T. (2005, Nisan). İmo İstanbul Şubesi 2005 İlkbaharYaz Dönemi Meslekiçi Eğitim Kursları. Betonarme Binalarda Deprem Perdelerinin Yerleşimi Ve Tasarımı.

Prajapati, M. N., Patel, V. V., \& Patel, B. R. (2016). Parameters Comparison For Different Structural System. International Research Journal Of Engineering And Technology (Irjet), 3(05), 1963-1966.

Sakcall, G. B. (2019, October). Betonarme Binalarda Perde Duvar Oranının Farklı Parametrelere Göre İncelenmesi. In International Conference On Earthquake Engineering And Seismology (5ICEES) (Vol. 8, P. 11).

SAP2000, Integrated finite element analysis and design of structures basic analysis reference manual, Computers and Structures, 2012, California, USA

Şahin, H., Alyamaç, K. E., \& Erdoğan, A. S. (2013). Perdeli Çerçeveli Yapılarda Zemin Sınıfı Ve Kat Adedi Dikkate Alınarak Gerekli Perde Oranının Tespiti. Sdu International Journal Of Technological Science, 5(1).

Uçar, T., \& Merter, O. (2009). Planda Perde Yerleşiminin Betonarme Perde-Çerçeveli Binaların Deprem Davranışına Etkisi. DEÜ

Yaman, S., Tekeli, H., \& Demir, F. (2019). Betonarme Binalarda Perde Yeri Değişiminin Bina Performansına Etkisi. Avrupa Bilim ve Teknoloji Dergisi, (16), 194-204. 